\title{
Teaching Accounting Courses Online: One Instructor's Experience
}

Gregory M. Dusing, Saint Joseph's University, USA

Jonathan C. Hosler, Saint Joseph's University, USA

Joseph M. Ragan, Saint Joseph's University, USA

\begin{abstract}
Accounting programs at colleges and universities across the country are offering more online courses, and in some cases entire degree programs. Given increasing enrollments in online accounting education, it is important that accounting educators become aware of the things that work and the things that don't work when delivering courses over the internet. This paper addresses the good and bad aspects of teaching accounting online. It looks at optimal ways to integrate state-of-the-art technology into an online teaching model and explores ways to increase effectiveness of online delivery as compared to traditional courses. This paper examines teaching accounting courses online at a small liberal arts school. Our research identifies features in the course that led to its effectiveness.
\end{abstract}

Keywords: Teaching Accounting Online; Teaching Online Courses; Online Education

\section{BACKGROUND AND PRIOR RESEARCH}

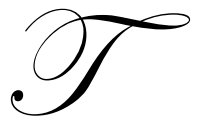

his paper responds to the need for increased perspectives on how to teach distance learning courses. Specifically, we investigate the various characteristics of communications technology and good pedagogy in the development of an online, distance learning environment. The anticipated contribution lies in two areas. One, it promises to strengthen our understanding of what factors affect student outcomes in this type of setting. Secondly, it promises to provide a deeper understanding of the different media characteristics that go into developing either synchronous or asynchronous online contexts that are technologically mediated.

In recent years, there has been a substantial increase in the number of educational institutions offering distance learning delivery models. The number of online courses has enjoyed a ten-fold growth from $6 \%$ to over $60 \%$ of colleges and universities offering some form of distance learning opportunity (Graves, 2008). The business world has also joined in the rush to offer their employees training at a distance. Hitt, Keats, and DeMarie (1998) argue that the leading drive for corporations lies in the promise of reduced downtime, travel expense, and cost efficiencies. In the new age of business, such savings are critical to gain competitive advantage.

Information technology suppliers ever eager to exploit this new business opportunity have rushed products to market that facilitate training at a distance (Robbins \& Butler, 2009). New information technologies offer innovative solutions to meet these challenges. Faster and more economical computing power, high-speed communications networks, and standardized interoperable software, and communications technology provide ways to link diverse locations into virtual learning environments (Shim, Shropshire, Park, Harris, \& Campbell, 2007). Alternatives are being developed to the model of learning where student and teacher are collocated in the same classroom at the same time (Beldarrain, 2006). Breaking the same time / same place paradigm provides flexibility in learning and often encourages greater communications ability in the model of delivery chosen (Durrington, Berryhill, Swafford, 2006).

The use of information technology to create learning climate has often been done without regard to the underlying processes of learning. The result has been the development of state-of-the-art facilities without clear 
guidelines on how the technology may be used to improve the learning backdrop (Leidner \& Jarvenpaa, 1995). Teachers may resort to traditional teaching methods. They either do not realize the potential of new technology or the technology is significantly inappropriate for the learning environment (Robbins \& Butler, 2009). The core issue lies in the challenge of understanding how the learning process is facilitated or hindered by physical and temporal distances, and what technologies can be used to overcome that distance (Hargreaves, 2005).

To address these questions and challenges, this paper is structured so as to: 1) Introduce one accounting professor's experience in the development of an online course within a university environment. 2) Provide an integrated list of internet tools and technologies that can enrich online classes; 3) Capture the fit between various teaching methods and their best uses in the delivery of a course; and 4) Highlight educational best practices for use in online teaching.

\section{COURSE DESIGN}

Pedagogical revisions have evolved within the graduate curriculum in Accounting at Saint Joseph's University, a liberal arts Jesuit institution within the Philadelphia market. The accounting program is housed within the Haub School of Business. The curriculum developed encompasses two broad categories. First, the creation of an accounting foundation course delivered on a traditional basis. This course assumes no prior knowledge of accounting and typical of most school is the first course offered in a graduate curriculum. Second, a course offered traditionally that also has sections for students who wish to take it online. This online option is just one year old and constitutes more than $60 \%$ of the student population being served. The course entitled Creating and Measuring Shareholder Value is designed to teach the basics of cost accounting and managerial accounting as applied to the real world of business. An important part of this course is the development of case based Microsoft Excel analysis and communication skills. The syllabus of the course in included in Appendix A and a schedule of reading and assignments is included in Appendix B.

A unique feature of the course pedagogy is the utilization of STAR Scholars to assist in development and delivery of this type of online course. These scholars are chosen through a highly selective process and specially trained to deal with the development and delivery of online courses. To date, there are some six STAR Scholars comprised mostly of seniors and graduate accounting students who have been specifically trained in the development of online courses. These students assist in classroom delivery and continue to service the course by maintaining a help desk for students. In addition they serve as technical support in the design of the course and the ongoing development of its delivery. Although actively involved in the course, they are not permitted access to assessment or course grading information.

In the development of this course we were very conscious of the charge of the Accounting Education Change Commission to produce individuals who possess the communication, intellectual, and interpretive skills necessary to succeed in the complex global environment and who have the commitment to lifelong learning to maintain continued success. As a part of this direction we see the growing development of online courses both in stand-alone courses and as a hybrid to support in-class instruction. Many faculty and administrators struggle with what it means to achieve quality in online education. Given our experience, we can provide a list of things that are requirements for an online course to be successful.

\section{KEY DRIVERS IN THE DELIVERY OF AN ONLINE COURSE}

\section{Interactive Classroom Tools}

The A550 course was developed after a series of attempts in similar courses. In this process, we were able to clearly define best practices with regard to technology tools we wanted to use. A feel for technology (both knowing what to use and how to use it) is critical for successful online teaching. Even on an asynchronous basis, students expect the online course to be enabled with state-of-the-art technology.

The online classroom is the major point of live interaction between instructors and students. The online classroom facilitates the live presentation of PowerPoint's, classroom problems, discussions, and student 
presentations. The typical online classroom includes features such as audio input, chat window, whiteboard, simple survey responses (yes and no), and hand raises. The online classroom looks to simulate as best as possible a student's experience in a physical classroom. When an online classroom is used the option to archive the class session for later viewing is available. The archive ability allows for students to replay the class session at a time that is convenient for them. The downfall of all online classrooms is the high bandwidth requirement. Participants should have a DSL or cable internet connection. The flow of the class is greatly degraded if bandwidth is not great enough.

Wimba - Wimba is a product that integrates very closely with Black Board. Wimba has been the primary online classroom we have used. In our experience, for both instructors and students, Wimba proved to be very stable and intuitive to use. The integration of Blackboard and Wimba has a stronghold in the higher education market. Clearly, this ifs preferred by universities to its availability with the Blackboard Learning Management System. A sample of the features of Wimba are presented in Appendix D.

Adobe Connect - As part of the adobe eLearning suite of products, Adobe launched Adobe Connect. Adobe connect can also be integrated with an Learning Management System (LMS). Adobe Connect has a strong presence in the professional world but it looking to strengthen its presence in higher education. The cost of this system is prohibitive for most universities.

WebEx - WebEx targets corporations and small business owners. WebEx facilitates on-the-fly virtual meetings. While this could be used in distance learning, WebEx does not closely integrate with LMSs.

\begin{tabular}{|l|l|l|}
\hline \multicolumn{1}{|c|}{ Interactive Classroom } & \multicolumn{1}{|c|}{ Pros } & \multicolumn{1}{|c|}{ Cons } \\
\hline Wimba & $\begin{array}{l}\text { Close integration with LMS. Rich } \\
\text { feature set. }\end{array}$ & Somewhat outdated interface. \\
\hline Adobe Connect & $\begin{array}{l}\text { Very current- Adobe continues to release } \\
\text { regular updates. Rich feature set. }\end{array}$ & $\begin{array}{l}\text { High cost. LMS integration requires } \\
\text { extra setup. }\end{array}$ \\
\hline WebEx & Does not require an LMS or much setup. & Little to no integration with LMS. \\
\hline
\end{tabular}

\section{Collaboration Tools}

Collaboration tools look to recreate class participation in a virtual environment. Since students do not meet face to face in distance learning environments, collaboration tools are crucial to ensure students are still achieving a high level of interaction with each other and the instructor.

Discussion Board - A discussion board or forum allows students to openly share their thoughts and ideas. Discussion boards are an ongoing conversation between participants. A typical discussion board focuses on one area or topic for discussion. Multiple discussion boards can be created to discuss different topics.

Wiki - A Wiki is a community driven body of knowledge. The most famous Wiki is the online encyclopedia Wikipedia. Wikis allow for students to build a course specific encyclopedia. Each student has access to view and edit the Wiki.

Blog - A Blog is a "Web Log". Blogs allow students to share their thoughts with other students. A post is the term given to an entry students make to their blog. Other students have the ability to comment on and react to other student's posts.

Videos - Videos can be created and uploaded for students to view. Videos can be created using a video camera or screen capture software. Popular software packages used to create videos are Adobe Premiere and Adobe Captivate.

Glossary - An online glossary can be built to help students learn key terms. The glossary may be built by the instructor or by the students in the class. 
Journals - Journals allow students to reflect on course material and allow an opportunity for feedback from the instructor. Online journals attempt to simulate a physical journal that would be submitted in class.

\begin{tabular}{|c|c|c|}
\hline Collaboration Tool & Pros & Cons \\
\hline Discussion Board & Easy to use. Simulates classroom discussion. & Communication is solely written. \\
\hline Wiki & $\begin{array}{l}\text { Community driven. Quickly develop a course } \\
\text { specific encyclopedia. }\end{array}$ & $\begin{array}{l}\text { Requires moderation to insure the content being } \\
\text { posted is correct. }\end{array}$ \\
\hline Blog & $\begin{array}{l}\text { Students can create content and easily share it } \\
\text { publically. Other students can post comments } \\
\text { regarding a post. }\end{array}$ & Limited interaction between students. \\
\hline Videos & $\begin{array}{l}\text { Very rich content can be delivered. Videos can } \\
\text { be easily reused from class to class. }\end{array}$ & Additional setup time to create a video. \\
\hline Glossary & Easily created and focused to course content. & Limited collaboration between students. \\
\hline Journals & $\begin{array}{l}\text { Students can share reactions with the instructor. } \\
\text { The interaction between the student and } \\
\text { instructor is private. }\end{array}$ & $\begin{array}{l}\text { Similar task can be accomplished using a Blog. } \\
\text { Journals should be used if the content is of a } \\
\text { private nature. }\end{array}$ \\
\hline
\end{tabular}

A key benefit of using Blackboard and other Learning Management Systems is sustaining the interdependence of course activities and the ability to present the same material through different forms. Students first saw the subject matter from direct discussion with the instructor and further developed their understanding of the subject matter by completing homework deliverables that were due on a weekly basis. The teaching philosophy of "learning by doing" is achieved using popular technology drivers such as MS Excel, Word or PowerPoint. The graduate course taught at St. Joseph's heavily emphasized MS Excel in preparing budget analysis worksheets, variance reports and basic financial statements. Our technology drivers explicitly developed a virtual learning process for students yet kept a consistent delivery model for the course curriculum. Students first reviewed course material via live Wimba whiteboard sessions with MS PowerPoint, then walked through sample task based home work deliverables via Wimba desktop share and MS Excel and lastly built and developed their own home work solutions for the deliverables required to submit. For those students who preferred to independently learn on their own without synchronous interaction with the instructor, the LMS provided ways for this to happen.

A challenge that both students and instructors face is the potential lack of interaction in a virtual learning environment due to the physical and temporal distance between them. Students in today's society are looking to online education because of the asynchronous capabilities and the comfort of the technology being used. Because dependency on technology is swiftly increasing, students want to be able to do the required work on their own schedule from the comfort of their own home. We provided this independent asynchronous learning environment to our graduate accounting students through the use of Adobe Captivate and Wimba archives. Two weeks prior to the first day of the course, the instructor and STAR Leader recorded one hour lectures for each chapter covered in the outlined syllabus. The Captivate presentations were unique because the accompanying PowerPoint presentations were narrated by the instructor's voice giving the students a sense of a close-knit classroom environment rather than a distant programmed virtual environment. The pre-recorded Captivate presentations were available to be viewed 24 hours a day from any computer. In addition to the pre-recorded chapter presentations, the live Wimba sessions were archived for future viewing. Students who missed the live sessions would be able to view what was covered or talked about in the prior weeks' classes. Once the students had covered the designated course content for the week, they were required to perform an assessment of learning either by means of a quiz or test.

\section{BEST PRACTICES AND LESSONS LEARNED}

1. A quality online course requires clearly defined learning objectives and well articulated expectations for learners. When preparing an online course, thorough planning becomes the critical first step. Essentially this boils down to what should be done versus what can or cannot be done. Greater emphasis is placed in a detailed expectations form (syllabus). 
2. Each online course should have a standard look and feel. Most universities have standardized templates that are used across curriculum in developing online courses. When developing new courses using a well established clear and consistent structure, quality course design and delivery naturally follows. The best success we've had is dividing a course into modules and structure and organizing assignments according to those modules. It is critical here to provide a schedule of deliverables (see Appendix B). A consistent design and structure helps students understand and navigate online coursework more easily. In this course, we used different course management systems, but the one we have found to be most effective is the Blackboard System.

3. Synchronous student interaction on a weekly basis was critical. We achieve this with open-ended discussion questions. These questions are loaded into a part of the Blackboard site that employs a threaded bulletin board or discussion board where students can append each question online. This is all done asynchronously. Students can post answers at different times and even change them if they choose. The number and nature of these discussion questions varies depending upon the preference of the instructor and the nature of the course (AppendixC).

4. The pace of delivery within an online course must be controlled. The question of how to pace the course is very important. Some students may fall behind. Others may choose to work well ahead of the rest of the class and post their answers to discussion questions and assignment answers early. We believe that pace needs to be time restricted. The Blackboard System can control when the various units of the course are made visible to the students. Allowing students to post early reduces the amount of dialogue between them, especially for the better students who are often the ones posting early. The point is that these questions will come up in an online class. An instructor is well advised to plan carefully and provide a detailed statement of what and when is expected at the beginning of the course.

5. Multiple course assessment opportunities are critical in an online environment. All the work is done as an open book. You can time manage the submission, which requires them to know the material, but they will still have the ability to access a book where the answer is obvious. In addition, the instructor does not know if a paper or assignment turned in by one student was actually written by another. Academic honesty policies need to be reviewed prior to setting up the course. We responded to each within 12 to 24 hours.

6. Listen to your students throughout the course and respond quickly to questions and problems that may arise.

\section{CONCLUSION AND IMPLICATIONS FOR FUTURE RESEARCH}

This paper preferred a practical framework for use by online course developers in the design of an online course. The framework focused on the development of an online graduate course at Saint Joseph's University, a private Jesuit institution located in Philadelphia, PA. One of the clear limitations of this article is that what works at a small school might not work as well at a larger school. The academic level of student taught may require a different approach. What works at a graduate level may not work well at an undergraduate level.

Much can be learned from a full understanding of online technology tools and the instructional methodology needed to deliver those tools well. The momentum for online education caused by this increase in technology and the World Wide Web will not be slowed down. An ongoing dialogue is needed among institutions and programs to determine what works and what does not work. An area we plan to explore further is the assessment of learning model needed for online courses.

\section{AUTHOR INFORMATION}

Gregory M. Dusing is a senior accounting major at Saint Joseph's University, USA.

Jonathan C. Hosler is a senior accounting major at Saint Joseph's University, USA.

Joseph M. Ragan, Saint Joseph's University, USA. Professor Ragan is Chair and Professor of accounting. His experience includes: PwC University, June 2005, SAP Training in Logistics, Financial, and Controlling Modules, 2000 - 2004, Certified Public Accountant, 1979, University of Pennsylvania, 1975, MBA (Accounting with minor in Business Policy), Villanova University, 1972, MA (Educational Administration), Saint Joseph's University, 1969, BA. E-mail: jragan@sju.edu. Corresponding author. 


\section{REFERENCES}

1. Alavi, M., Wheeler, B.C, and Valacich, J.S. (1995) "Using IT to reengineer business education: An exploratory investigation of collaborative telelearning," MIS Quarterly, Vol. 19, No. 3, pp. 293-312.

2. Astani, M., Johnson, B., and Ready, K.J., (2011) "Design and Implementation Issues in Integrating elearning: Lessons Learned from a Fortune 1000 Firm," The Business Review, Cambridge, Vol. 18, No. 1, pp. 1-7.

3. Beldarrain, Y. (2006) "Distance Education Trends: Integrating New Technologies to foster student interaction and collaboration," Distance Education, Vol. 27, No. 2, pp. 139-153.

4. Bradley, W. E., (2011) "A Conceptual Framework for the Design and Evaluation of Online Learning Modules in Professional Training and Academic Education in Business," The Business Review, Cambridge, Vol. 18, No. 1, pp. 20-27.

5. Castelluccio, M. (2006) "Inventing New Media—the Podcast," Strategic Finance, Vol. 87, No. 9, pp. 5758 .

6. Durrington, V.A., Berryhill, A. and Swafford, J. (2006) "Strategies for Enhancing Student Interactivity in an Online Environment," College Education, Vol. 54, No. 1, pp. 190-193.

7. Graves, L. (2008) A Second Life for Higher Ed: A Virtual World Offers New Opportunities for Teaching. U.S. News \& World Report, Retrieved May 8, 2010, from http://www.usnews.com/articles/education/elearning/2008/01/10/a-second-life-for-higher-ed.html

8. Green, D.T. (2008) "Using Student Video Presentations in an Online Course," Decision Sciences Journal of Innovative Education, Vol. 6, No. 2, pp. 521-526.

9. Hallam, T.A. and Hallam S.F. (2009) "Combining an Exciting Classroom Learning Environment with an Effective Computerized Learning Management System," Journal of Applied Research for Business Instruction, Vol. 7, No. 2, pp. 1-6.

10. Hargreaves, E. (2005) "Assessment for learning? Thinking Outside the (Black) Box," Cambridge Journal of Education, Vol. 35, No. 2, pp. 213-224.

11. Hitt, M.A., Keats, B.W., and DeMarie, S.M. (1998) "Navigating in the new competitive landscape: Building strategic flexibility and competitive advantage in the $21^{\text {st }}$ century," The Academy of Management Executive, Vol. 12, No. 4, pp. 22-42.

12. Leidner, D.E., and Jarvenpaa, S.L. (1995) "The use of information technology to enhance management school education: A theoretical view," MIS Quarterly, Vol. 19, No. 3, pp. 265.

13. McKeachie, W.J., Svinicki, M.D. and Hofer, B.K. (2006) Mckeachie's Teaching Tips: Strategies, Research, and Theory for College and University Teachers, $12^{\text {th }}$ Edition. Houghton Mifflin, Boston, MA.

14. Meine, M.F. and Dunn, T.P (2009) "Testing Integrity in Online Courses: Big Brother has Arrived," PA Times, Vol. 10, No. 02, p. 6

15. Mindel, J.L and Verma, S. (2006) "Wikis for Teaching and Learning," Communications of AIS, Vol. 18, No. 6, pp. 2-38.

16. Robbins, R.W. and Butler, B.S. (2009) "Selecting a Virtual World Platform for Learning," Journal of Information Systems Education, Vol. 20, No. 2, pp. 199-210

17. Schiller, S. (2009) "Practicing Learner-Centered Teaching: Pedagogical Design and Assessment of a Second Life Project," Journal of Information Systems Education, Vol. 20, No. 3, pp. 369-381.

18. Shim, J.P., Shropshire, J., Park, S., Harris, H. and Campbell, N. (2007) "Podcasting for e-Learning, Communication, and Delivery," Industrial Management \& Data Systems, Vol. 107, No. 4, pp. 587-600.

19. Tallent-Runnels, M.K., Thomas, J.A., Lan W.Y., Cooper, S., Ahern, T.C, Shaw, S.M. and Liu, X. (2006) "Teaching Courses Online: A Review of the Research," Review of Educational Research, Vol. 76, No. 1, pp. 93-135.

20. Watson, R.T., Boudreau, M.C., York, P.T., Greiner, M. and Wynn, D.E. (2008) "Opening the Classroom," Journal of Information Systems Education, Vol.19, No. 1, pp. 75-85.

21. Webster, J., and Hackey, P. (1997) "Teaching effectiveness in technology-mediated distance learning," Academy of Management Journal, Vol. 40, No. 6, pp. 1282-1309.

22. West, R., Waddoups, G. and Graham, C. (2007) "Understanding the Experiences of Instructors as they Adopt a Course Management System," Educational Technology Research and Development. Vol. 55, No. 1 , pp. 1-26. 


\title{
APPENDIX A
}

\section{$\underline{\text { ACC } 550 \text { OL - Creating \& Measuring Shareholder Value }}$}

\author{
TEXTBOOK Managerial Accounting, Ronald W. Hilton, $9^{\text {th }}$ edition; Irwin McGraw-Hill; 2011; ISBN 978-0- \\ REQUIRED 07-811091-7
}

\section{COURSE DESCRIPTION}

The course is designed to help you understand the role of managerial accounting in creating values for the organization. It shows how the internally generated accounting information is used as a basis for managerial decision-making. Topics covered will include the balances scorecard, activity-based costing system, performance evaluation and cost-volume-profit analysis. The courses also emphasizes how management planning and control can have behavioral (social) and ethical implications on the organization and the individuals involved.

\section{IMPORTANT NOTICE TO STUDENTS}

This section of ACC 550 is being offered as an online course. To participate, students must have a reliable Internet connection to the Saint Joseph's University Blackboard site (http://blackboard9.sju.edu). Access through high-speed cable or DSL is strongly recommended.

Students should be online regularly throughout the course to access audio module introductions and narrated slide presentations as well as participate in "discussion board threads," to submit assignments and to take quizzes and exams. All course materials, documents, notices, etc. will be posted on the Blackboard course site, which can be accessed directly as noted above or through MySJU.

The SJU MBA Office has scheduled these sections for a TBA time slot - although the class will not be meeting face-to-face, a Wednesday time slot will be used for any scheduled Live Classroom sessions where students will be online with the professor. During this semester, a maximum of seven (7) Live Classroom sessions have been scheduled on Wednesday's at 7:00 p.m. These sessions will be used primarily for a brief lecture focusing on "where we've been, where we are and where we're going" in the course. Some computational problem examples will typically be provided and students are encouraged to participate as well as review the sessions, which will be archived on the Blackboard course site. Student attendance/participation is optional for these sessions but is strongly recommended. Please see the Schedule of Readings and Assignments posted in the Schedule/Due Dates link on the Blackboard site for specific date information. The online class sessions will run for approximately 60 to 90 minutes. For those students who have another SJU class scheduled during the same time as our live sessions I will be archiving each of the sessions for later viewing so there is no problem with your not participating with us live. You will be able to view the archive and contact me with any additional questions you may have.

Previous experience indicates that the majority of student/professor interaction tends to take place on a one-on-one basis via e-mail. E-mail typically works well for student questions regarding technical subject matter as it allows for detailed responses as well as computations and illustrations where appropriate in response to questions. Inasmuch as e-mail will be used extensively, please read the following section that describes the e-mail policy for this course.

\section{E-MAIL POLICY}

As noted above, e-mail is a very effective means of communication in an online course. Students are encouraged to use e-mail to contact the professor. Every effort will be made to answer all e-mails within two working days of the date and time of receipt (Sunday is not considered a working day) - under normal circumstances, e-mails will be answered on the day received, assuming they arrive prior to 6:00 p.m. Students may e-mail the professor directly iragan@sju.edu. Alternately, students may use the "E-mail" function of Blackboard to send e-mails to the professor and/or other members of the class. 


\section{APPENDIX B}

Accounting 550

Creating \& Measuring Shareholder Value

Spring 2010

Schedule of Readings and Assignments

\begin{tabular}{|c|c|c|c|c|c|}
\hline Week of & Subject & Webinar: Topic & Readings & Homework & Deliverables (due date) \\
\hline 1/16/11 & $\begin{array}{l}\text { Introduction - } \\
\text { Syllabus } \\
\text { MODULE } 1\end{array}$ & $\begin{array}{l}\text { 1/19/11 - Overview of } \\
\text { Module } 1\end{array}$ & $\begin{array}{l}\text { Chapter } 1 \\
\text { Chapter } 2\end{array}$ & $\begin{array}{l}\text { Ch 1-Problem } 1 \\
\text { Ch 2-E29, E30 } \\
\text { Problem 2-38 }\end{array}$ & $\begin{array}{l}\text { Case 1-33 (1/21) } \\
\text { Problem 2-43 (1/21) }\end{array}$ \\
\hline $1 / 23 / 11$ & MODULE 2 & $\begin{array}{l}\text { 1/26/11 - Overview of } \\
\text { Module } 2\end{array}$ & $\begin{array}{l}\text { Chapter } 3 \\
\text { Chapter } 5\end{array}$ & $\begin{array}{l}\text { Ch 3-E 32, E } 35 \\
\text { Problem 3-48 } \\
\text { Ch5-Problem } 45 \\
\end{array}$ & $\begin{array}{l}\text { Problem 3-50 (1/28) } \\
\text { Problem 5-52 (1/28) } \\
\text { Case 5-68 (1/28) } \\
\end{array}$ \\
\hline 1/31/11 & $\begin{array}{l}\text { MODULE } 3 \\
\text { Review for } \\
\text { Exam } 1\end{array}$ & $\begin{array}{l}\text { 2/2/11 - Overview of } \\
\text { Chapter } 7 \& \\
\text { Review for Exam I }\end{array}$ & Chapter 7 & $\begin{array}{l}\text { E 31, E } 33 \\
\text { Problems 7-34, } \\
7-35\end{array}$ & $\begin{array}{l}\text { Problem 7-42 (2/4) } \\
\text { Exam I } \\
\text { Chapters 1, 2, } 3 \text { \& } \mathbf{5}\end{array}$ \\
\hline $2 / 6 / 11$ & MODULE 3 & $\begin{array}{l}2 / 9 / 11- \\
\text { Overview of Chapter } 9\end{array}$ & Chapter 9 & $\begin{array}{l}\text { E 27, E 29 } \\
\text { Problem 9-33 }\end{array}$ & Problem 9-40 (2/11) \\
\hline $2 / 13 / 11$ & MODULE 4 & $\begin{array}{l}2 / 16 / 11- \\
\text { Overview of Chapters } 9 \\
\& 10\end{array}$ & Chapter 10 & $\begin{array}{l}\text { E 28, E } 32 \\
\text { Problem 10-42, } \\
10-44\end{array}$ & Case 10-62 (2/18) \\
\hline $2 / 20 / 11$ & MODULE 4 & $\begin{array}{l}2 / 23 / 11- \\
\text { Overview of Chapter } 12\end{array}$ & Chapter 12 & $\begin{array}{l}\text { E } 33 \\
\text { Problem 12-44 }\end{array}$ & Case 12-51 (2/25) \\
\hline $2 / 27 / 11$ & MODULE 4 & $\begin{array}{l}\text { 3/1/11 } * *(\text { Tuesday) } \\
\text { Overview of Chapter } 13\end{array}$ & Chapter 13 & $\begin{array}{l}\text { E } 24, \text { E } 25, \text { E } 26 \\
\text { Problem 13-36, } \\
13-43\end{array}$ & Problem 13-45 (3/4) \\
\hline $3 / 6 / 11$ & $\begin{array}{l}\text { Review for } \\
\text { Final Exam }\end{array}$ & No Webinar & **Review** & **Review** & $\begin{array}{l}\text { Final Exam is posted on } \\
\text { Thursday, March } 10^{\text {th }} \text { (Due } \\
3 / 13 \text { ) }\end{array}$ \\
\hline $3 / 13 / 11$ & FINAL EXAM & & Comprehensive & & FINAL EXAM (3/13) \\
\hline
\end{tabular}

*All deliverables are due on the specified date by MIDNIGHT 


\section{APPENDIX C}

Blackboard Site showing access to discussion question and discussion thread

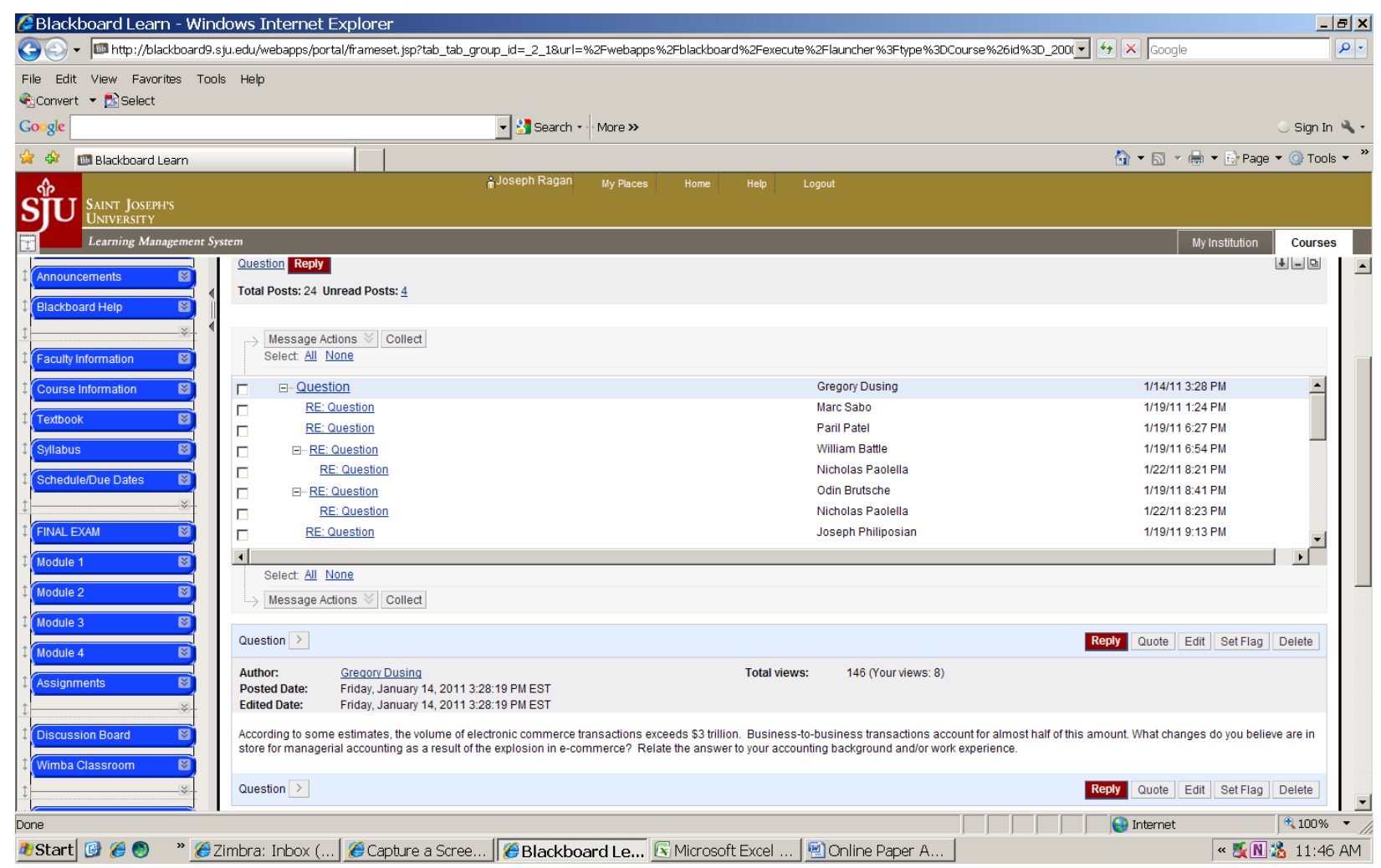




\section{APPENDIX D}

\section{The Power of Wimba as an online teaching tool}

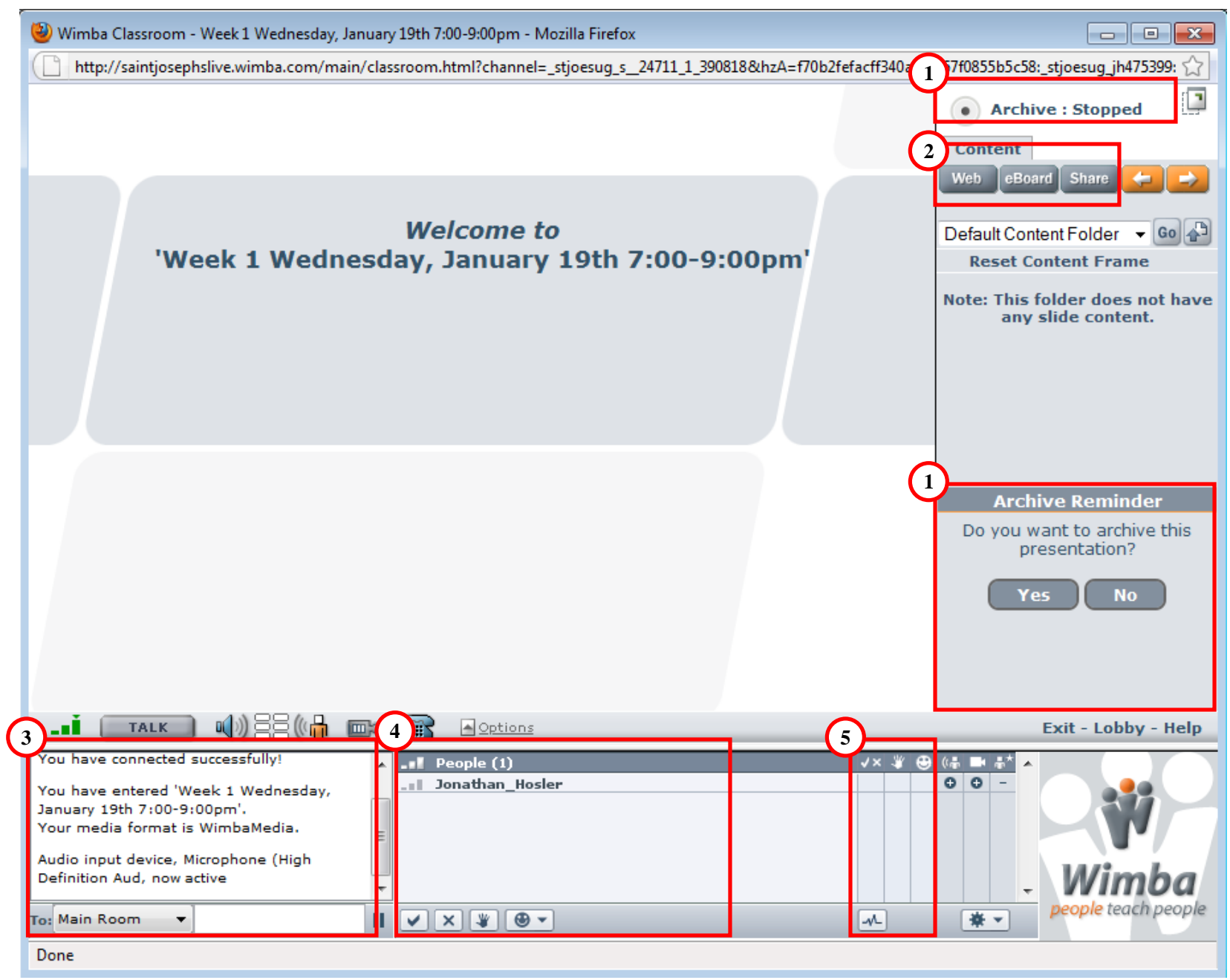

\begin{tabular}{|c|l|}
\hline Number & Function \\
\hline 1 & Archive the presentation to view later. \\
\hline 2 & Share content with participants. \\
\hline 3 & Chat window for using during the session. \\
\hline 4 & Listing of participants. \\
\hline 5 & Status of the participants. \\
\hline
\end{tabular}

